\title{
Isolation of Group Specific Products from Lactobacillus casei and $L$. casei var. rhamnosus
}

\author{
By K. W. KNOX \\ Institute of Dental Research, United Dental Hospital, Sydney, Australia
}

(Received 23 July 1962)

\section{SUMMARY}

An examination has been made of serologically reactive products obtained from four strains of Lactobacillus casei (serological groups B and C) and two strains of Lactobacillus casei var. rhamnosus (serological group C). Cell wall preparations were hydrolysed with a preparation of Streptomyces muralytic enzyme and the soluble indiffusible products isolated. Rhamnose is the major component of both the cell wall and soluble extracts from group B organisms, whereas glucose is the major component of preparations from $L$. case $i$ group C. Two products differing considerably in composition have been isolated from each strain of L. casei var. rhamnosus.

The serological properties of the preparations have also been studied and the results confirm that strains of Lactobacillus casei can be divided into two serological groups. It is concluded that group B specificity is primarily dependent on rhamnose and group $\mathrm{C}$ specificity on glucose, which is probably joined by a 1-6 $\beta$ linkage to the adjacent sugar. The two fractions isolated from $L$. case $i$ var. rhamnosus differ in their serological properties; antibodies formed on injection of this organism are predominantly directed against one component (in fraction $\mathrm{I}$ ) whereas extracts react with sera against strains of $L$. case $i$ group $\mathrm{C}$ because of the presence of a second component (in fraction II).

\section{INTRODUCTION}

In an extensive serological study of lactobacilli Sharpe (1955a) found that $70 \%$ of the strains tested could be classified into six groups and one subgroup. It was shown that a serological group may contain more than one species and further that organisms classified as Lactobacillus casei could be divided into two serological groups, one of which also contained organisms designated L. helveticus. Subsequently Sharpe \& Wheater (1957) proposed that the species previously defined as $L$. helveticus be renamed $L$. casei var. rhamnosus and that the serological groups be referred to by letters, group B including $L$. case $i$ and group C including $L$. case $i$ and L. casei var. rhamnosus. Sharpe used hot dilute acid extracts of lactobacilli for her serological studies. However, to investigate the chemical basis of the serological specificity of $L$. casei a milder technique for obtaining soluble extracts was considered desirable and a previous report (Knox \& Brandsen, 1962) described the isolation of serologically active soluble products from autolysed cell wall of a strain of $L$. casei (group B). This technique was found to have restricted application and the present report describes the properties of products released by Streptomyces albus enzymes from the cell wall of Lactobacillus of serological groups B and C. This 
streptomyces enzyme system was shown by McCarty $(1952 b, 1956,1958)$ to dissolve the cell wall of Streptococcus of Lancefield group A, the soluble products including the group-specific carbohydrate hapten.

\section{METHODS}

Organisms. Cultures of Lactobacillus used by Sharpe (1955a) were obtained from the National Collection of Type Cultures, Colindale, London (designated NCTC), the National Institute for Research in Dairying, Reading, England (NIRD) and the National Collection of Industrial Bacteria, Torry Research Station, Aberdeen, Scotland ( $\mathrm{NCIB})$. These organisms were Lactobacillus casei NIRD strain $\mathrm{H} 831$ and L. casei NIRD DECP belonging to group B, and $L$. casei NIRD R 094 and L. helveticus NCTC 6375 of group C. A strain of L. delbrueckii (NCIB 7473) has also been included, since the wall of this strain was shown by Cummins \& Harris (1956) to contain rhamnose, a characteristic component of the cell wall of $\boldsymbol{L}$. casei. However, on the basis of physiological and serological tests this strain is considered to be $L$. casei var. rhamnosus (group C). The laboratory strain 55 of L. casei (group B) used in previous studies (Knox \& Brandsen, 1962) was also included in the current investigation.

Culture media. Cultures for inoculation into rabbits and for the preparation of $\mathrm{HCl}$ extracts were grown at $37^{\circ}$ in the appropriate media described by Sharpe $(\mathbf{1 9 5 5} b)$. Washed organisms were suspended in $0.4 \%$ formaldehyde $+0.9 \% \mathrm{NaCl}$ solution and injected intramuscularly in rabbits every 3-4 days for a 4-week period. Organisms for disintegration and isolation of cell wall were grown in the medium described by Agren \& de Verdier (1958).

Preparation of cell wall. Suspensions of organisms (equivalent to about $25 \mathrm{mg}$. dry wt./ml.) were shaken with Ballotini No. 12 glass beads in a Mickle disintegrator for $1 \mathrm{hr}$. (Salton \& Horne, 1951). The cell-wall residue was suspended in $\mathrm{M} / 15$ phosphate (pH 7.8) heated at $100^{\circ}$ for $20 \mathrm{~min}$. (to inactivate cell-wall autolysing enzymes) and then digested with crystalline trypsin and ribonuclease (Armour Laboratories, Eastbourne, England) as described by Cummins \& Harris (1956). The wall preparation was subsequently washed repeatedly with $\mathrm{M} / \mathbf{1 5}$ phosphate buffer $(\mathrm{pH} 7 \cdot 2)$ then with water and dried from the frozen state.

Analytical methods. Methods for the determination of nitrogen, glucose, rhamnose, hexosamines and amino acids were as described previously (Knox \& Brandsen, 1962). The galactose content of preparations was calculated from the total hexose value, determined by the basic cysteine reaction (Dische, 1949). Galactose and rhamnose gave 90 and $5 \%$, respectively, of the amount of colour given by an equal weight (200 $\mu \mathrm{g}$.) of glucose. The reproducibility of the results for wall preparations was improved by hydrolysing samples for $2 \mathrm{hr}$. at $100^{\circ}$ in $\mathrm{N}-\mathrm{H}_{2} \mathrm{SO}_{4}$ before carrying out the estimations.

Preparation of the Streptomyces albus muralytic enzyme. Murphy (1960) suggested that 'muralytic enzyme' be used as a generic term for those enzymes which lyse bacteria by dissolving the cell wall. McCarty $(1952 a, b)$ showed that certain strains of Streptomyces albus possessed a muralytic enzyme acting on streptococci; cultures of $\boldsymbol{S}$. albus with such activity were provided by Dr M. McCarty (Rockefeller Institute, New York, U.S.A.) and Dr J. A. Hayashi (College of Medicine, University of Illinois, Chicago, U.S.A.). Other strains of Streptomyces isolated from soil by the technique described by Salton (1955) were less effective. 
The Streptomyces albus enzyme was prepared by the method described by McCarty $(1952 a, b)$. After precipitation by $70 \%$ saturation with $\left(\mathrm{NH}_{4}\right)_{2} \mathrm{SO}_{4}$ in the presence of Filter-Cel (Johns-Manville, Lompoc, California, U.S.A.), the enzyme was dissolved in $\mathrm{M} / 15$ phosphate buffer ( $\mathrm{pH} 8$ ); this solution was used for dissolving cell wall without further fractionation. As measured by the decrease in optical density (at $620 \mathrm{~m} \mu$ ) the enzyme was capable of dissolving the cell wall of each of the strains of Lactobacillus examined, although there were differences in the speed.

\section{RESULTS}

\section{Properties of the streptomyces muralytic enzyme}

A preparation of wall from Lactobacillus strain NCTC $6375(40 \mathrm{mg}$. in $20 \mathrm{ml}$. water) was incubated at $37^{\circ}$ with $4 \mathrm{ml}$. of dialysed enzyme (dialysis at $2^{\circ}$ against distilled water did not affect the activity of the enzyme preparation). The rate of

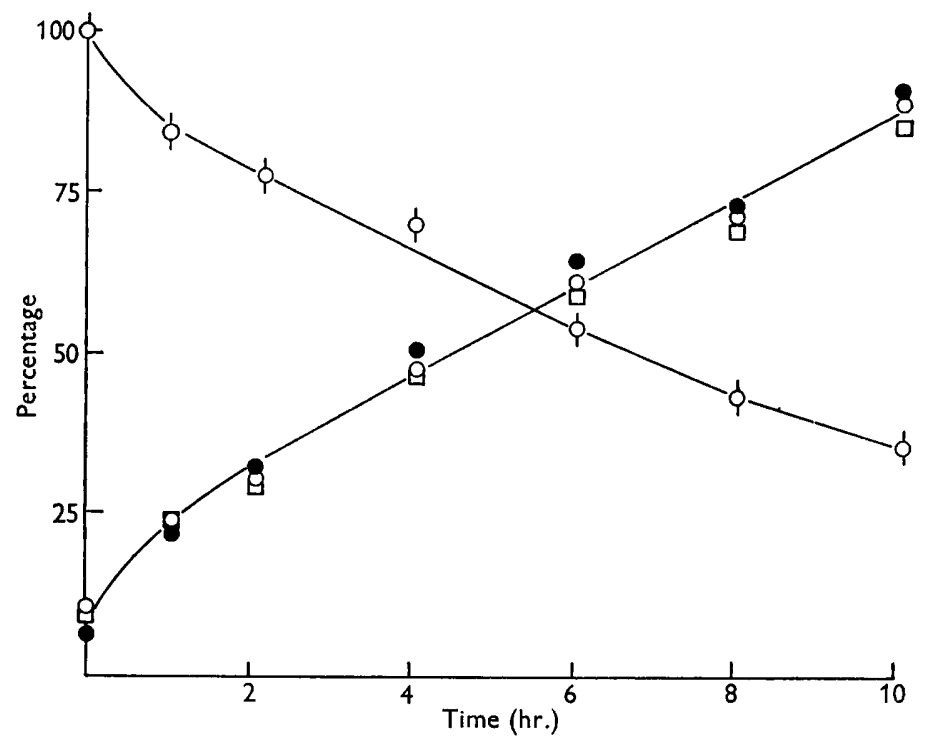

Fig. 1. The lysis of cell wall of Lactobacillus strain NCTC 6375 by streptomyces enzyme. The decrease in optical density $(\phi)$ is expressed as percentage of the starting value. The amount of rhamnose ( $\square)$, glucose $(O)$ and hexosamine $(O)$ in the soluble fraction is expressed as percentage of the total amount in the sample of cell wall.

decrease in optical density at $620 \mathrm{~m} \mu$ was followed (using $\frac{1}{2}$ in. tubes in a Unicam SP 1400 Absorptiometer) and at appropriate intervals a $2 \mathrm{ml}$. sample was removed and added to $2 \mathrm{ml}$. $\mathrm{N}-\mathrm{H}_{2} \mathrm{SO}_{4}$. The cell wall residue was removed by centrifugation, the supernatant fluid heated at $100^{\circ}$ for $4 \mathrm{hr}$. to hydrolyse the polysaccharides, and the rhamnose, glucose and hexosamine contents determined. In Fig. 1 the rate of release of these components is compared with the rate of decrease in optical density.

The optimal $\mathrm{pH}$ value for enzyme activity was determined by following the rate of decrease in optical density in $\mathrm{M} / 15$ phosphate buffer at $\mathrm{pH}$ values between $\mathbf{5 \cdot 3}$ and 8.0. (At $\mathrm{pH}$ values below 5.0 the wall flocculated.) The maximum rate of enzyme action was observed between $\mathrm{pH} 5 \cdot 3$ and 6.5 , with decreasing activity at 
higher values. For instance, in $2 \mathrm{hr}$. at $\mathrm{pH} \mathbf{5 \cdot 9}$ the optical density decreased by $36 \%$ as compared with $27 \%$ at $\mathrm{pH} 8.0$; incubation for $3 \mathrm{hr}$. at $\mathrm{pH} 8$ was required to decrease the optical density by $36 \%$.

After incubation for $3 \mathrm{hr}$. the suspensions were heated to inactivate the muralytic enzyme ( $100^{\circ}$ for $20 \mathrm{~min}$.), centrifuged and the supernatant fluid dialysed. The rhamnose and glucose contents of the indiffusible fraction were then determined. The results supported the conclusion that maximum enzymic activity was obtained between $\mathrm{pH} \mathrm{5.3}$ and 6.5. Again, comparing the results at $\mathrm{pH} \mathrm{5.9}$ and $8 \cdot 0$, the amounts of soluble rhamnose and glucose at $\mathrm{pH} 8$ represented 57 and $62 \%$, respectively, of the values obtained at $\mathrm{pH} 5 \cdot 9$. At all $\mathrm{pH}$ values between $5 \cdot 3$ and 8.0 there was no significant change in the relative molar proportions of rhamnose and glucose present in the indiffusible fraction.

Most of the soluble polymers containing rhamnose and glucose were indiffusible. A preparation of wall from Lactobacillus strain NIRD $\mathrm{H} 831$ was suspended in water and incubated for $18 \mathrm{hr}$. at $37^{\circ}$ with dialysed streptomyces enzyme. The cell wall residue was then removed by centrifugation and the supernatant fluid dialysed at $2^{\circ}$. Of the total soluble rhamnose, glucose and glucosamine, only $2-4 \%$ was present in diffusible polymers, whereas $27 \%$ of the total muramic acid was diffusible. No monosaccharides were detectable.

\section{Analysis of cell wall preparations}

As shown previously (Knox \& Brandsen, 1962), the wall of Lactobacillus strain 55 contains rhamnose, galactose and glucose in addition to the characteristic components of the cell wall (glucosamine, muramic acid, glutamic acid, aspartic acid, lysine and alanine).

The cell wall preparations from each of the five additional strains also contain rhamnose, glucose, glucosamine, galactosamine and muramic acid. All except Lactobacillus strain NIRD DECP contain galactose and strain NCIB 7473 in addition contains mannose. The results of the quantitative analyses for these components are given in Table 1. The major difference in the preparations from the different strains lies in the relative molar proportions of rhamnose and glucose; the values for this ratio are given in Table 2.

The major amino acids of the cell wall of each strain were: glutamic acid, aspartic acid, lysine, alanine. In contrast to the wide range of rhamnose and glucose values there was a much greater constancy in the molar proportions of the amino acids present in the wall. The molar ratios of glutamic acid, aspartic acid, lysine and alanine for the six strains fell within the range $1 \cdot 0: 0 \cdot 6-1 \cdot 2: 0 \cdot 7-1 \cdot 0: 1 \cdot 6-2 \cdot 0$.

\section{Preparation of cell wall carbohydrates}

In earlier experiments, the mixture of cell wall and muralytic enzyme was incubated at $\mathrm{pH} 8$ as suggested by McCarty $(1952 b)$. When it was observed that a more rapid dissolution of cell wall occurred at or below $\mathrm{pH} 6.5$ experiments were made at $\mathrm{pH} \mathrm{5 \cdot 3}$. To illustrate the procedure for obtaining soluble cell wall products the results of a typical experiment at $\mathrm{pH} 8$ will be described. A preparation of cell wall from Lactobacillus NIRD $\mathrm{H} 831$ (900 $\mathrm{mg}$. in $50 \mathrm{ml}$. M/15 phosphate buffer) was incubated at $37^{\circ}$ with an equal volume of streptomyces enzyme preparation. To 
follow the rate of cell wall lysis, a sample $(0.3 \mathrm{ml}$.) was removed and diluted with $4.0 \mathrm{ml} . \mathrm{M} / 15$ phosphate buffer ( $\mathrm{pH} \mathrm{8.0)}$. The optical density of this suspension fell from 0.62 to 0.28 in $18 \mathrm{hr}$. and to 0.26 in $24 \mathrm{hr}$. After $24 \mathrm{hr}$. the remainder of the suspension was centrifuged and $\left(\mathrm{NH}_{4}\right)_{2} \mathrm{SO}_{4}$ added to the supernatant fluid to $70 \%$

Table 1. Comparison of the composition of cell wall preparations and soluble products liberated by streptomyces enzyme

\begin{tabular}{|c|c|c|c|c|c|c|c|}
\hline Lactobacillus strain & Fraction & $\begin{array}{c}\text { Rhamnose } \\
(\%)\end{array}$ & $\begin{array}{c}\text { Glucose } \\
(\%)\end{array}$ & $\begin{array}{c}\text { Galac- } \\
\text { tose } \\
(\%)\end{array}$ & $\begin{array}{c}\text { Hexos- } \\
\text { amine* } \\
(\%)\end{array}$ & $\begin{array}{c}\text { Muramic } \\
\text { acid } \\
(\%)\end{array}$ & $\begin{array}{c}\text { Nitrogen } \\
(\%)\end{array}$ \\
\hline L. casei NIRD H 831 & $\begin{array}{l}\text { Wall } \\
\text { I } \\
\text { II }\end{array}$ & $\begin{array}{l}33 \\
31 \\
48\end{array}$ & $\begin{array}{l}2 \cdot 0 \\
4 \cdot 2 \\
3 \cdot 6\end{array}$ & $\frac{7}{7}$ & $\begin{array}{l}16 \cdot 2 \\
15 \cdot 0 \\
24 \cdot 2\end{array}$ & $\begin{array}{l}9 \cdot 8 \\
6 \cdot 5 \\
5 \cdot 2\end{array}$ & $\begin{array}{l}7 \cdot 6 \\
6 \cdot 4 \\
3 \cdot 6\end{array}$ \\
\hline L. casei NIRD DECP & $\begin{array}{l}\text { Wall } \\
\text { I } \\
\text { II }\end{array}$ & $\begin{array}{l}26 \\
18 \cdot 5 \\
39\end{array}$ & $\begin{array}{r}11 \cdot 5 \\
6 \cdot 1 \\
17\end{array}$ & $\frac{0}{0}$ & $\begin{array}{r}11 \cdot 2 \\
9 \cdot 6 \\
18 \cdot 4\end{array}$ & $\begin{array}{l}3 \cdot 8 \\
3 \cdot 8 \\
2 \cdot 0\end{array}$ & $\begin{array}{l}6 \cdot 6 \\
8 \cdot 5 \\
4 \cdot 2\end{array}$ \\
\hline L. casei strain 55 & $\begin{array}{l}\text { Wall } \\
\text { I } \\
\text { II }\end{array}$ & $\begin{array}{l}28 \\
16 \\
41\end{array}$ & $\begin{array}{l}11 \\
4 \cdot 2 \\
13\end{array}$ & $\frac{14}{16}$ & $\begin{array}{r}16 \cdot 0 \\
7 \cdot 4 \\
18 \cdot 8\end{array}$ & $\begin{array}{l}8 \cdot 2 \\
1 \cdot 0 \\
2 \cdot 2\end{array}$ & $\begin{array}{l}4 \cdot 8 \\
9 \cdot 9 \\
2 \cdot 3\end{array}$ \\
\hline L. casei NIRD R 094 & $\begin{array}{l}\text { Wall } \\
\text { I } \\
\text { II }\end{array}$ & $\begin{array}{l}1 \cdot 5 \\
3 \cdot 0 \\
1 \cdot 7\end{array}$ & $\begin{array}{l}12 \cdot 5 \\
11 \\
27 \cdot 5\end{array}$ & $\frac{13}{23}$ & $\begin{array}{r}17 \cdot 6 \\
8 \cdot 6 \\
21 \cdot 2\end{array}$ & $\begin{array}{r}12 \cdot 0 \\
\mathbf{2} \cdot 8 \\
5 \cdot 8\end{array}$ & $\begin{array}{l}8 \cdot 2 \\
9 \cdot 1 \\
3 \cdot 8\end{array}$ \\
\hline L. helveticus NCTC 6375 & $\begin{array}{l}\text { Wall } \\
\text { I } \\
\text { II }\end{array}$ & $\begin{array}{c}24 \\
46 \\
2 \cdot 0\end{array}$ & $\begin{array}{l}22 \cdot 5 \\
33 \\
28\end{array}$ & $\begin{array}{l}12 \\
18 \\
27\end{array}$ & $\begin{array}{r}5 \cdot 0 \\
1 \cdot 0 \\
14 \cdot 0\end{array}$ & $\begin{array}{l}1 \cdot 0 \\
0 \cdot 0 \\
1 \cdot 0\end{array}$ & $\begin{array}{l}4 \cdot 8 \\
1 \cdot 9 \\
3 \cdot 9\end{array}$ \\
\hline L. delbrueckii NCIB 7473 & $\begin{array}{l}\text { Wall } \\
\text { I } \\
\text { II }\end{array}$ & $\begin{array}{c}28 \\
56 \\
9 \cdot 1\end{array}$ & $\begin{array}{l}23 \\
35 \\
34\end{array}$ & $\begin{array}{r}18 \dagger \\
0 \ddagger \\
24 \S\end{array}$ & $\begin{array}{c}6 \cdot 8 \\
1 \\
20 \cdot 0\end{array}$ & $\begin{array}{l}4 \cdot 0 \\
0 \cdot 0 \\
2 \cdot 8\end{array}$ & $\begin{array}{l}4 \cdot 5 \\
1 \cdot 2 \\
3 \cdot 5\end{array}$ \\
\hline
\end{tabular}

* Glucosamine + galactosamine; $\dagger$ includes mannose; $\ddagger$ contains $9 \%$ mannose (determined by basic cysteine reaction); $\S$ includes trace of mannose.

Table 2. Molar ratios of rhamnose and glucose in cell wall preparations and isolated soluble products of certain strains of Lactobacillus

$\begin{array}{cl}\begin{array}{c}\text { Serological } \\ \text { group }\end{array} & \begin{array}{c}\text { Lactobacillus } \\ \text { strain }\end{array} \\ \text { B } & \text { NIRD H 831 } \\ & \text { NIRD DECP } \\ & \text { strain 55 } \\ & \text { NIRD R 094 } \\ \text { C } & \text { NCTC 6375 } \\ & \text { NCIB 7473 }\end{array}$

\begin{tabular}{ccc} 
Molar ratio of rhamnose to glucose \\
\hline Wall & Fraction I & Fraction II \\
18.4 & 8.6 & 14.8 \\
2.5 & $3 \cdot 4$ & $2 \cdot 6$ \\
2.8 & 4.4 & 3.5 \\
0.13 & 0.30 & 0.09 \\
1.19 & 1.54 & 0.08 \\
1.34 & 1.77 & 0.30
\end{tabular}

saturation. At this level, the enzyme and possibly the cell wall components would be precipitated. The precipitate was dissolved in distilled water, and both the precipitate (fraction I) and the supernatant fluid (fraction II) from the $\left(\mathrm{NH}_{4}\right)_{2} \mathrm{SO}_{4}$ fractionation dialysed and the non-diffusible portions dried from the frozen state. The yields of cell wall residue, fraction I and fraction II, were $120 \mathrm{mg}$, $60 \mathrm{mg}$. and $550 \mathrm{mg}$. respectively. Fraction II was also the major product obtained from strains NIRD DECP, 55 and NIRD R 094; for the other two strains (NCTC 6375 and 
NCIB 7473) fraction I was the major component. For each of the six strains under examination the composition of fractions I and II has been compared with that of the wall (Table 1 ).

\section{Analysis of cell wall carbohydrates}

Fraction I. For four strains (Lactobacillus NIRD R 094 and the three strains of group B) the fraction precipitated by $70 \%\left(\mathrm{NH}_{4}\right)_{2} \mathrm{SO}_{4}$ represented only a small amount of the total soluble material; the analyses (Table 1) indicated that the products contained all the components of the cell wall. Enzyme protein would be contributing to the total nitrogen, which in two instances was considerably higher than the nitrogen content of the wall.

The preparations of fraction I from Lactobacillus NCTC 6375 and NсIB 7473 differed in composition from those obtained from the other strains, the nitrogen and hexosamine values being low and muramic acid absent. Rhamnose and glucose were the major components in each case, the remaining sugar being either galactose (strain NCTC 6375) or mannose (strain NCIB 7473). The nitrogen content of fraction I from these two strains could be lowered by further fractionation. The preparation was dissolved in ethylene glycol $(1 \% \mathrm{w} / \mathrm{v})$ and acetone added; $50 \%(\mathrm{v} / \mathrm{v})$ acetone precipitated a small amount of material, the bulk of the material (fraction $\mathrm{I} b$ ) being precipitated by $55 \%(\mathrm{v} / \mathrm{v})$ acetone. For instance, fraction $\mathrm{I} b$ from strain NCTC 6375 contained $51 \%$ rhamnose, $37 \%$ glucose, $20 \%$ galactose and $0.4 \%$ nitrogen $(1.9 \%$ nitrogen in fraction $I)$.

Fraction II. Preparations of fraction II contained all the cell wall components including the amino acids, glutamic acid, aspartic acid, lysine and alanine; quantitative analyses for carbohydrates and nitrogen are given in Table 1. Preparations from Lactobacillus strains in serological group B had rhamnose : glucose ratios comparable to those of the cell wall preparations. Preparations from strains in serological group $\mathrm{C}$ were similar in composition with low rhamnose:glucose ratios (Table 2).

Three observations on the results in Tables 1 and 2 are relevant to the subsequent serological studies. First, organisms in serological group B have a higher rhamnose: glucose ratio than those in group $\mathrm{C}$; this applies both to the cell wall preparations and to the soluble fractions. Secondly, preparations of fraction II from Lactobacillus strains of serological group $\mathrm{C}$ have a low rhamnose: glucose ratio. Thirdly, for each of the strains of Lactobacillus casei var. rhamnosus in serological group $\mathrm{C}$ (i.e. strains NCTC 6375 and NCIB 7473) fractions I and II differ considerably in compositionfraction I being composed almost entirely of rhamnose and glucose and fraction II containing much less rhamnose but the carbohydrate components of the mucopeptide.

\section{Further fractionation of fraction $\boldsymbol{I I}$}

In previous work (Knox $\&$ Brandsen, 1962) it was shown that the soluble material obtained on autolysis of cell wall from Lactobacillus strain $\mathbf{5 5}$ could be fractionated into products of different composition by dissolving in ethyleneglycol and precipitating with increasing amounts of acetone; the major difference between the fractions was in the relative amounts of rhamnose and glucose, the molar ratios varying between $0 \cdot 9: 1$ and $5 \cdot 0: 1$. In the present work it was found that fraction II from strain 55 also yields products of differing composition. From $100 \mathrm{mg}$. of 
material was obtained (a) $28 \mathrm{mg}$. fraction II $a$, precipitated by $50 \%(\mathrm{v} / \mathrm{v})$ acetone, and containing 50\% rhamnose and $12 \%$ glucose (ratio $4 \cdot 6: 1$ ); (b) $40 \mathrm{mg}$. fraction II $b$, precipitated by $60 \%(\mathrm{v} / \mathrm{v})$ acetone, and containing $50 \%$ rhamnose and $10.5 \%$ glucose (ratio 5•3:1); and (c) $18 \mathrm{mg}$. fraction II $c$, precipitated by $65 \%(\mathrm{v} / \mathrm{v})$ acetone $+1 \%(\mathrm{w} / \mathrm{v}) \mathrm{NaCl}$, and containing $19 \%$ rhamnose and $16.5 \%$ glucose (ratio 1·3:1). Fraction II from strain NIRD DECP was also fractionated in a similar manner but a separation into products of different rhamnose:glucose ratios was not achieved.

Serological examination of soluble cell wall products

Sharpe (1955 $a$ ) studied the antigenic relationship between strains of Lactobacillus casei and $L$. helveticus by the qualitative precipitin test. Sera prepared against $L$. casei NIRD H 831 and $L$. casei NIRD DECP were used for classifying organisms in the $L$. casei group (subsequently called group B) and sera prepared against $L$. casei NIRD R 094 and $L$. helveticus NCTC 6375 for classification in the $L$. casei-helveticus group (group C). L. casei strain 55 and $L$. delbrueckii NCIB 7473 were examined by this procedure and, as stated previously, it is concluded that these two strains belong to serological groups $\mathrm{B}$ and $\mathrm{C}$ respectively. The division of these organisms into two groups has been confirmed by studying the serological properties of the products liberated by the Streptomyces enzyme.

Table 3. Cross reaction between antisera to three strains and the soluble products (fraction II) isolated from cell wall preparations of certain strains of Lactobacillus

In each case $10 \mu \mathrm{g}$. of preparation was mixed with $0.1 \mathrm{ml}$. of serum in a final volume of $1.0 \mathrm{ml}$. The values are expressed as \% of amount of precipitate obtained in the homologous reaction. When results are not listed the values were not significantly greater than those given by the blank containing serum and saline.

$\begin{array}{lrrr}\begin{array}{c}\text { Lactobacillus } \\ \text { source of } \\ \text { Fraction II }\end{array} & \overbrace{\text { H831 }} & \begin{array}{c}\text { DECP } \\ \%\end{array} & \text { R094 } \\ \text { NIRD H 831 } & \overbrace{100}^{\text {Antiserum }} & 73 & - \\ \text { NIRD DECP } & 70 & 100 & - \\ \text { Strain 55 } & 110 & 90 & - \\ \text { NIRD R094 } & - & - & 100 \\ \text { NCTC 6375 } & - & - & 84 \\ \text { NCIB 7473 } & - & - & 98\end{array}$

Fraction $I$. The preparation of fraction I from Lactobacillus NCTC 6375 and NCIB $\mathbf{7 4 7 3}$ reacted strongly with antisera to strain NCTC 6375 and also to strain NCIB $\mathbf{7 4 7 3}$ but gave no detectable precipitate with antiserum to strain NIRD R094. An indication of the extent of cross reaction with antiserum to strain NCTC 6375 was obtained by the quantitative precipitin test. Solutions of fraction I from each strain were diluted to $20 \mu \mathrm{g} . / \mathrm{ml}$. in $0.9 \% \mathrm{NaCl}$ and $0.5 \mathrm{ml}$. mixed with $0.5 \mathrm{ml}$. serum which had been diluted fivefold. Experiments were set up in triplicate. After $1 \mathrm{hr}$. at $37^{\circ}$ and 2-3 days at $4^{\circ}$ the protein content of the precipitate was determined by the method of Heidelberger \& MacPherson (1943) by using Folin \& Ciocalteu's phenol reagent. It was found that the preparation from strain NCIB 7473 gave $98 \%$ of the amount of precipitate given by NCTC 6375. A comparison of 
the two preparations by the Ouchterlony method (Ouchterlony, 1953) showed the presence of a single serologically identical component.

Fraction II. Preparations were tested against each of the four group sera by the qualitative precipitin test. The results agreed with those obtained for acid extracts, although only weak cross reactions were obtained between antisera to Lactobacillus NCTC 6375 and the organisms of group C. An indication of the extent of cross reaction between the six strains was obtained by the quantitative precipitin test. Experiments were set up in triplicate against antisera to strains NIRD H 831, NIRD DECP and NIRD R094, using the same conditions as described above for fraction I. In Table 3 the amount of precipitin obtained is expressed as a percentage of that given in the homologous reaction.

The observations were extended to include a study by the Ouchterlony technique (Ouchterlony, 1953), each of the six preparations of fraction II being tested against antisera to Lactobacillus NIRD H 881 (serological group B) and NIRD R 094 (serological group C). The test revealed only one component; within each serological group the fractions were shown to be serologically identical and no cross reaction between the groups was detectable.

\section{Inhibition of precipitin reaction by component sugars}

The effectiveness of $25 \mu$ moles of rhamnose, galactose and glucose in inhibiting the precipitin reaction between antisera and fractions I and II was studied (Table 4). The amounts of antiserum and polysaccharide used were found suitable by preliminary studies in which the proportions of antiserum and polysaccharide were varied. The antiserum $(0.2 \mathrm{ml}$. for group $B$ organisms and $\mathbf{0} \cdot 1 \mathrm{ml}$. for group $\mathrm{C}$ organisms) was mixed with $25 \mu$ moles of rhamnose or glucose in a final volume of $0.5 \mathrm{ml}$. After $1 \mathrm{hr}$. at $37^{\circ}, 0.5 \mathrm{ml}$. of solution containing the appropriate amount of polysaccharide was added and the amount of precipitate formed on standing was estimated as described previously.

Table 4. Inhibition of precipitin reaction between antisera and preparations of fractions I and II by 25 moles of rhamnose, glucose or galactose

\begin{tabular}{|c|c|c|c|c|c|c|}
\hline \multirow{2}{*}{$\begin{array}{l}\text { Sero- } \\
\text { logical } \\
\text { group }\end{array}$} & \multirow{2}{*}{$\begin{array}{c}\text { Lactobacillus } \\
\text { strain }\end{array}$} & \multicolumn{2}{|c|}{ Amount of component added } & \multicolumn{3}{|c|}{ Inhibition (\%) } \\
\hline & & Fraction & Serum & Rhamnose & Glucose & Galactose \\
\hline \multirow[t]{3}{*}{$\mathbf{B}$} & NIRD H 831 & $20 \mu \mathrm{g}$. II & $0.2 \mathrm{ml}$. H 831 & 55 & $\mathbf{0}$ & 4 \\
\hline & NIRD DECP & $10 \mu \mathrm{g}$. II & $0.2 \mathrm{ml}$. DECP & 60 & 7 & 一 \\
\hline & Strain 55 & $\begin{array}{l}25 \mu \mathrm{g} \text {. II } \\
25 \mu \mathrm{g} \text {. II } b \\
25 \mu \mathrm{g} \text {. II } c\end{array}$ & $\begin{array}{l}0.2 \mathrm{ml} .55 \\
0.2 \mathrm{ml} .55 \\
0.2 \mathrm{ml} .55\end{array}$ & $\begin{array}{l}47 \\
50 \\
30\end{array}$ & $\begin{array}{l}14 \\
14 \\
27\end{array}$ & $\begin{array}{l}25 \\
-\end{array}$ \\
\hline \multirow[t]{3}{*}{ C } & NIRD R 094 & $5 \mu \mathrm{g}$. II & $0.1 \mathrm{ml} . \mathrm{R} 094$ & 11 & 25 & 3 \\
\hline & NCTC 6375 & $\begin{array}{l}10 \mu \mathrm{g} . \text { I } \\
10 \mu \mathrm{g} . \text { II }\end{array}$ & $\begin{array}{l}0.1 \mathrm{ml} .6375 \\
0.1 \mathrm{ml} . \text { R } 094\end{array}$ & $\begin{array}{r}10 \\
0\end{array}$ & $\begin{array}{l}24 \\
26\end{array}$ & $\begin{array}{l}4 \\
2\end{array}$ \\
\hline & NCIB 7473 & $\begin{array}{l}10 \mu \mathrm{g} . \text { I } \\
10 \mu \mathrm{g} . \text { II }\end{array}$ & $\begin{array}{l}0 \cdot 1 \mathrm{ml} .6375 \\
0 \cdot 1 \mathrm{ml} . \mathrm{R} 094\end{array}$ & $\begin{array}{l}7 \\
4\end{array}$ & $\begin{array}{l}19 \\
34\end{array}$ & $\begin{array}{l}0 \\
7\end{array}$ \\
\hline
\end{tabular}

Fraction I. For examining preparations of fraction I from Lactobacillus NCTC 6375 and NCIB 7473, antiserum to strain NCTC 6375 gave satisfactory results. Although fraction I from strain NCIB $\mathbf{7 4 7 3}$ reacted strongly with the homologous antiserum 
it was not possible to obtain more than $4 \%$ inhibition of the precipitin reaction, even with $100 \mu$ moles of rhamnose or glucose.

Fraction II. All preparations of fraction II from organisms of group B were tested using the homologous antiserum. Antiserum to Lactobacillus NIRD R 094 was used for studies on fraction II from group C organisms. The study of strain 55 was extended to include fractions II $b$ and II $c$, the products separated by acetone precipitation from ethyleneglycol in which the rhamnose:glucose ratios were $5 \cdot 1: 1$ and $1 \cdot 3: 1$ respectively.

\section{Further studies on the glucose specificity of group C organisms}

The ability of a number of glucosides to inhibit the precipitin reactions between antisera to organisms of group $\mathrm{C}$ and corresponding fractions has been studied, using the same conditions as those described above. The sugars employed were methyl- $\alpha$-D-glucopyranoside, methyl- $\beta$-D-glucopyranoside and all the reducing disaccharides containing glucose units joined by $\beta$ linkages-sophorose $(1 \rightarrow 2)$, laminaribiose $(1 \rightarrow 3)$, cellobiose $(1 \rightarrow 4)$ and gentiobiose $(1 \rightarrow 6)$.

Fraction $I$. The inhibition of the reaction of fraction $I$ from Lactobacillus NCTC 6375 with homologous antiserum was studied. Methyl- $\beta$-D-glucoside was more effective than methyl- $\alpha$-D-glucoside, the respective values for $25 \mu$ moles being 28 and $20 \%$ compared with $24 \%$ for glucose. None of the disaccharides was more effective than methyl- $\beta$-D-glucoside.

Table 5. Effect of periodate oxidation for $8 \mathrm{~min}$. at room temperature on the component sugars and serological activity of fractions $I$ and II

\begin{tabular}{|c|c|c|c|c|}
\hline \multirow[b]{2}{*}{ Lactobacillus strain } & \multirow[b]{2}{*}{ Fraction } & \multicolumn{2}{|c|}{$\begin{array}{c}\text { Amount of component } \\
\text { remaining (expressed as \% } \\
\text { of starting value) }\end{array}$} & \multirow{2}{*}{$\begin{array}{c}\text { Serological } \\
\text { reactivity } \\
\text { (amount of } \\
\text { precipitate } \\
\text { expressed } \\
\text { as \% of } \\
\text { starting } \\
\text { value) }\end{array}$} \\
\hline & & Rhamnose & Glucose & \\
\hline NIRD H 831 & II & 54 & - & 26 \\
\hline NIRD R 094 & II & - & 81 & 62 \\
\hline NCIB 7473 & II & 100 & 78 & 48 \\
\hline NCIB 7473 & I & 109 & 84 & 69 \\
\hline NCTC 6375 & I & 108 & 83 & 74 \\
\hline
\end{tabular}

Fraction II. Methyl- $\beta$-D-glucoside was also more effective than methyl- $\alpha$-Dglucoside in inhibiting the reaction between fraction II from Lactobacillus NIRD R 094 and homologous antiserum, the inhibition by $25 \mu$ moles being $42 \%$ compared with $12 \%$ (25\% by glucose). The extent of inhibition by $10 \mu$ moles of disaccharide has been studied; gentiobiose gave $33 \%$ inhibition, whereas the remaining disaccharides, as well as methyl- $\beta$-D-glucoside (10 $\mu$ moles) gave $21-24 \%$ inhibition. With smaller amounts (4 $\mu$ moles) of carbohydrate the corresponding values for gentiobiose and methyl- $\beta$-D-glucoside were 24 and $14 \%$ respectively. 


\section{Action of periodate on group specific products}

Under the same conditions as those adopted by Foster, Davies \& Crumpton (1958) preparations were oxidized for 3 and $8 \mathrm{~min}$. and subsequently reduced by sodium borohydride. Samples were then analysed for component sugars, and for serological activity by the quantitative precipitin test; the amounts of components used in the precipitin test were the same as those given in Table 4. The results of the effect of periodate for $8 \mathrm{~min}$. are summarized in Table 5 .

Serological group $B$. Rhamnose is responsible for the serological specificity of Lactobacillus strains of group B, and for a strain in this group (NIRD H 831) it was found that almost half the rhamnose was oxidized in $8 \mathrm{~min}$. This result indicates that the rhamnose units are joined by either a $1 \rightarrow 2$ or a $1 \rightarrow 4$ linkage.

Serological group $C$. Glucose is responsible for the serological specificity of both products which have been isolated from group $\mathrm{C}$ organisms. The glucose units in fraction II from Lactobacillus NIRD R 094 and NCIB 7473 were oxidized by periodate, oxidation being accompanied by reduction in serological reactivity. In the absence of more complete analyses, it is only possible to state that glucose units responsible for serological specificity are joined by $1 \rightarrow 2,1 \rightarrow 4$ or $1 \rightarrow 6$ linkages. The glucose units in fraction I from strain NCIB 7473 and NCTC 6375 were also oxidized by periodate. Rhamnose is a major component of fraction $I$ from these two strains but in each case the rhamnose was stable to periodate, the oxidation of other sugars actually resulting in an increase in the rhamnose content of the remaining residue. This result suggests that either the rhamnose units are joined by $1 \rightarrow 3$ linkages or, alternatively, that two of the three hydroxyl groupings (on positions $2,3,4$ ) of rhamnose are substituted.

\section{DISCUSSION}

The work described in the present paper was undertaken in an attempt to establish a relationship between components of the cell wall of Lactobacillus case $i$ and the serological properties of the particular organism. The characteristic components of the cell wall of Gram-positive bacteria include mucopolysaccharides, mucopeptides and teichoic acids. Only some species of lactobacilli contain teichoic acid in the cell wall, although in others glycerol teichoic acid has been detected within the cells (Baddiley \& Davison, 1961). Further, the presence of glycerol teichoic acid or ribitol teichoic acid in the wall could be related to the serological grouping of the particular organism, those in groups $\mathbf{A}$ and $\mathbf{E}$ containing glycerol and those in group D containing ribitol. Organisms of groups B, C and F contained no wall teichoic acid but an intracellular glycerol teichoic acid. This compound has been isolated from a strain of $L$. casei and its structure elucidated (Keleman \& Baddiley, 1961). The results of Baddiley \& Davison (1961) suggest that the teichoic acids participate in the serological reactions of some strains of lactobacilli, but not those of groups B and C, i.e. those designated L. casei or L. casei var. rhamnosus; in these organisms therefore another component of the cell wall must be associated with serological specificity.

Cummins \& Harris (1956) studied the cell wall composition of lactobacilli (and other organisms) and their results showed that only two of the strains examined contained rhamnose, one designated Lactobacillus casei (NCIB 8079) and the other 
L. delbrueckii (NCIB 7473). The latter has subsequently been shown to be a strain of L. casei var. rhamnosus (group C) so that it seemed likely that a knowledge of the occurrence of cell wall polysaccharides containing rhamnose might be valuable in the designation of organisms as $L$. casei. Examination of a laboratory strain $\mathbf{5 5}$ of L. case $i$ showed that rhamnose was a major component of the wall and was, together with galactose and glucose, associated with the serological specificity (Knox \& Brandsen, 1962). In the present investigation, cell wall components of five other strains of $L$. casei were studied, four of these having been used by Sharpe (1955 a) to distinguish between organisms of groups $\mathbf{B}$ and $\mathbf{C}$. To investigate the group specific products of these strains of $L$. casei the technique developed by McCarty was used. McCarty (1952b) incubated organisms of group A streptococci with Streptomyces albus enzyme and obtained soluble products containing the group specific carbohydrate. The preparation also contained the components of the cell wall mucopeptide, but subsequently it was shown that formamide would separate the polysaccharide from the mucopeptide (Krause \& McCarty, 1961).

The analyses of the soluble products obtained from cell wall following digestion with the streptomyces muralytic enzyme are given in Table 1. Fraction $I$ in each case was the product precipitated by $70 \%$ saturation with $\left(\mathrm{NH}_{4}\right)_{2} \mathrm{SO}_{4}$ (this was the concentration of $\left(\mathrm{NH}_{4}\right)_{2} \mathrm{SO}_{4}$ required to precipitate the enzyme), and fraction II was the material then remaining in the supernatant fluid. When the analyses for the wall and these two fractions from each of the four strains designated Lactobacillus casei are examined, three observations emerge: (i) for any one strain, the relative proportion of rhamnose and glucose in the two fractions is similar to that in the wall; (ii) each preparation of fraction II contains more hexosamine (glucosamine +galactosamine) and less muramic acid than the corresponding wall; (iii) from the analyses for nitrogen, fraction II preparations contain only a minor peptide component, whereas fraction I preparations contain less carbohydrate and a greater proportion of peptide. As it has also been observed that the diffusible fraction following enzyme action contains relatively large amounts of muramic acid, the results suggest the streptomyces enzyme is hydrolysing specific linkages in the cell wall mucopeptide. Krause \& McCarty (1961) have reached the same conclusion from their studies on the action of the streptomyces enzyme on streptococcal cell wall.

With the two strains of Lactobacillus casei var. rhamnosus a different pattern is obvious. In each case fraction I differed significantly in composition from fraction II, fraction I having a much greater content of rhamnose and virtually no hexosamine or peptide component (following further fractionation from ethylene glycol with acetone). The difference is even more pronounced for strain NCIB 7473; fraction I contained mannose but not galactose, whereas galactose was a major component of fraction II and mannose only a minor component. The results indicate that the wall of strains of $L$. casei var. rhamnosus contains two polysaccharide components. One component, in fraction II, is almost devoid of rhamnose and is also present in strain NIRD R 094 (group C). The other component, fraction I, contains most of the rhamnose, and it may be concluded that a polysaccharide composed of galactose, glucose and rhamnose represents about half the weight of the wall. The presence of this major cell wall polysaccharide in strains of $L$. casei var. rhamnosus is associated with a decrease in the mucopeptide fraction, the hexosamine, muramic acid 
and nitrogen values being considerably less than those for the other group $\mathrm{C}$ organism, strain NIRD R 094. Fractions I and II differ considerably in composition but from studies on the rate of dissolution of the wall (Fig. 1) there is no evidence for the two polysaccharide fractions being released at different rates; further, the rate of release was not affected by changes in $\mathrm{pH}$ between $5 \cdot 3$ and $8 \cdot 0$. There is no evidence, therefore, that enzymes of different specificity are acting on the cell wall to release the polysaccharide components. The small amount of hexosamine and nitrogen in preparations of fraction I may be indicative that this fraction is also released from the cell wall by hydrolysis of specific linkages in the mucopeptide.

From the analytical figures it is possible to calculate the percentage of the dry weight of the fractions which has been accounted for. This has been done for the six preparations of fraction II and the preparations of fraction I from the two strains of Lactobacillus casei var. rhamnosus. Assuming that the hexosamines are acetylated and that the total nitrogen is accounted for by amino acids and hexosamines, the percentage recovery lies between 91 and $98 \%$, with an average of $95 \%$ (allowing for water of hydrolysis). Thus it seems unlikely that any of the preparations contain significant amounts of undetected components.

Qualitative and quantitative precipitin studies have confirmed the conclusion of Sharpe (1955a) that strains of Lactobacillus casei can be divided into two groups, subsequently designated B and C (Sharpe \& Wheater, 1957). Rhamnose is the major component of the products obtained from group $\mathbf{B}$ organisms and it is also the most effective inhibitor of the precipitin reaction between the corresponding fraction II preparations and homologous antiserum. Further, the periodate oxidation of rhamnose residues in fraction II is accompanied by a decreased serological reactivity. Galactose and glucose contribute to the serological specificity of strain 55, and the cell walls apparently contain a polysaccharide component (isolated as fraction II $c$ ) in which these two sugars are important components. A fraction with similar properties has also been isolated from autolysed cell walls of strain 55 (Knox \& Brandsen, 1962). However, when the analytical and serological results for the two strains NIRD DECP and NIRD $\mathrm{H} \mathbf{8 3 1}$ are compared, it is apparent that galactose and glucose could not be contributing to their cross reaction. It may therefore be concluded that the classification of organisms as 'group B' depends on specific carbohydrate components which contain rhamnose, with some strains (such as 55) containing galactose and/or glucose as additional antigenic determinants.

Group C organisms comprised one strain of Lactobacillus casei NIRD R 094, containing only a small amount of rhamnose in the cell wall, and two strains of L. casei var. rhamnosus, in which rhamnose is a major component of the wall. Fractionation of the soluble products, released from each of the latter two strains by the streptomyces muralytic enzyme, showed most of the rhamnose was present in fraction $\mathrm{I}$ (precipitated by $\left(\mathrm{NH}_{4}\right)_{2} \mathrm{SO}_{4}$ ) whereas fraction II contained a much smaller amount of rhamnose and was very similar in composition to fraction II from $L$. casei NIRD R 094. The preparations of fraction II from strains of $L$. case $i$ var. rhamnosus cross react with antisera to NIRD $\mathrm{R} 094$ but do not give a precipitate with homologous antiserum, this reaction being given only by fraction I. It is concluded therefore that strains of $L$. casei var. rhamnosus cross react with strains of $L$. case $i$ in group $\mathrm{C}$ because of the presence of one specific antigenic determinant with a low rhamnose to glucose ratio (in fraction II), whereas antibodies produced on 
injection of these organisms are predominantly specific for another antigenic determinant with a greater rhamnose to glucose ratio (in fraction I). Sharpe (1955 $a$ ) observed that cultures of $L$. casei var. rhamnosus grown at $37^{\circ}$ stimulated the production of predominantly type serum, whereas with $L$. casei incubation at $37^{\circ}$ gave organisms which favoured the formation of group antibodies. It therefore appears probable that fraction I contains the type specific product and fraction II the group specific product.

The major components of fraction II from group $\mathbf{C}$ organisms are galactose and glucose, but only glucose is a significant inhibitor of the precipitin test. Additional studies indicate that the specific determinant contains glucose joined to the adjacent sugar by a $\beta$ linkage, the adjacent sugar probably being glucose substituted in the 6 position. Rhamnose is the major component of fraction I from the two strains of Lactobacillus casei var. rhamnosus but again glucose is the most efficient inhibitor. However, studies on the inhibition of glucosides gave results which do not clearly define the specificity in more detail, although it is probable that once again glucose is joined to the adjacent sugar by a $\beta$ linkage. Periodate oxidation studies showed that the rhamnose units in fraction I from Lactobacillus casei var. rhamnosus and fraction II from $L$. casei group B are joined by different linkages, probably $\mathbf{1} \rightarrow \mathbf{3}$ for the former and either $1 \rightarrow \mathbf{2}$ or $\mathbf{1} \rightarrow \mathbf{4}$ for the latter. The results for the preparation from $L$. casei var. rhamnosus could also be accounted for by a highly branched structure in which every rhamnose unit is substituted on two of the three hydroxyl groups; such a structure, however, would appear less probable.

This work was supported by a grant from the National Health \& Medical Research Council of Australia. I wish to thank Dr M. McCarty and Dr J. A. Hayashi for cultures of Streptomyces albus and Dr B. A. Stone for preparations of methyl- $\beta$ D-glucoside, sophorose and laminaribiose.

\section{REFERENCES}

Ågren, G. \& de Verdier, C.-H. (1958). The isolation of protein-bound phosphorylmuramic acid from Lactobacillus casei. Acta chem. scand. 12, $192 \%$.

Baddiley, J. \& Davison, A. L. (1961). The occurrence and location of teichoic acids in lactobacilli. J. gen. Microbiol. 24, 295.

Cummins, C. S. \& Harris, H. (1956). The chemical composition of the cell wall in some Gram-positive bacteria and its possible value as a taxonomic character. J. gen. Microbiol. 14, 583.

Dische, Z. (1949). Spectrophotometric method for the determination of free pentose and pentose in nucleotides. J. biol. Chem. 181, 379.

Foster, A. B., Davies, D. A. L. \& Crumpton, M. J. (1958). Action of periodate on some polysaccharides containing aldopeptose sugars. Nature, Lond. 181, 412.

Heidelberger, M. \& MacPherson, C. F. C. (1943). Quantitative microestimation of antibodies in the sera of man and other animals. Science, 97, 405.

Keleman, M. V. \& Baddiley, J. (1961). Structure of the intracellular glycerol teichoic acid from Lactobacillus casei, ATCC 7469. Biochem. J. 80, 246.

Knox, K. W. \& Brandsen, JANICE (1962). The isolation of components from the cell wall of Lactobacillus casei. Biochem. J. 85, 15.

KraUSE, R. M. \& MCCARTy, M. (1961). Studies on the chemical structure of the streptococcal cell wall. I. The identification of a mucopeptide in the cell walls of groups $A$ and A-variant streptococci. J. exp. Med. 114, 127. 
McCarty, M. $(1952 a)$. The lysis of Group A hemolytic streptococci by extra-cellular enzymes of Streptomyces albus. I. Production and fractionation of the lytic enzymes. J. exp. Med. 96, 555.

McCarTy, M. (1952b). The lysis of Group A hemolytic streptococci by extracellular enzymes of Streptomyces albus. II. Nature of the cellular substrate attacked by the lytic enzymes. J. exp. Med. 96, 569.

McCARTy, M. (1956). Variation in the group-specific carbohydrate of group A streptococci. II. Studies on the chemical basis for serological specificity of the carbohydrates. J. exp. Med. 104, 629.

McCarty, M. (1958). Further studies on the chemical basis for serological specificity of group A streptococcal carbohydrate. J. exp. Med. 108, 311.

MuRPhy, J. S. (1960). An agent derived from B. megaterium phage $G$ which dissolves the bacterial cell wall. Virology, 11, 510.

OUChTERLONY, Ö. (1953). Antigen-antibody reactions in gels. IV. Types of reaction in coordinated systems of diffusion. Acta path. microbiol. scand. 32, 231.

SALton, M. R. J. (1955). Isolation of Streptomyces spp. capable of decomposing preparations of cell walls from various microorganisms and a comparison of their lytic activities with those of certain Actinomycetes and Myxobacteria. J. gen. Microbiol. 12, 25.

Salton, M. R. J. \& Horne, R. W. (1951). Methods of preparation and some properties of cell walls. Biochim. biophys. Acta, 7, 177.

Sharpe, M. E. (1955a). Serological classification of lactobacilli. J. gen. Microbiol. 12, 107.

Sharpe, M. E. $(1955 b)$. Haptene substances in culture media for lactobacilli. J. gen. Microbiol. 13, 198.

Sharpe, M. E. \& Wheater, D. M. (1957). Lactobacillus helveticus. J. gen. Microbiol. 16, 676. 